\title{
Cost-effectiveness of screening for hepatitis C in Canada
}

\author{
William W.L. Wong PhD, Hong-Anh Tu PhD, Jordan J. Feld MD MPH, Tom Wong MD MPH, \\ Murray Krahn MD MSc
}

\begin{abstract}
Background: The seroprevalence of hepatitis $C$ virus (HCV) infection among Canadians is estimated at $0.3 \%$ to $0.9 \%$. Of those with chronic HCV infection, $10 \%$ to $20 \%$ will experience advanced liver disease by 30 years of infection. Targeted screening seems a plausible strategy. We aimed to estimate the health and economic effects of various screening and treatment strategies for chronic HCV infection in Canada.
\end{abstract}

Methods: We used a state-transition model to examine the cost-effectiveness of 4 screening strategies: no screening; screen and treat with pegylated interferon plus ribavarin; screen and treat with pegylated interferon and ribavarinbased direct-acting antiviral agents; and screen and treat with interferon-free direct-acting antivirals. We considered Canadian residents in 2 age groups: 25-64 and 45-64 years of age. We obtained model data from the literature. We predicted deaths related to chronic HCV infec- tion, costs, quality-adjusted life-years (QALYs) and incremental cost-effectiveness ratios.

Results: We found that screening and treating would prevent at least 9 HCV-related deaths per 10000 persons screened over the lifetime of the cohort. Screening was associated with QALY increases of 0.0032 to 0.0095 and cost increases of $\$ 124$ to $\$ 338$ per person, which translated to an incremental cost-effectiveness ratio of $\$ 34359$ to $\$ 44034$ per QALY gained, relative to no screening, depending on age group screened and antiviral therapy received.

Interpretation: A selective one-time HCV screening program for people 25-64 or 45-64 years of age in Canada would likely be cost-effective. Identification of silent cases of chronic HCV infection and the offer of treatment when appropriate could extend the lives of Canadians at reasonable cost.
Competing interests: Jordan Feld has received grants and/or consulting fees from AbbVie, Boehringer Ingelheim, Bristol-Myers Squibb, Gilead Sciences, Janssen, Merck, Roche and Theravance. No other competing interests were declared.

This article has been peer reviewed.

Correspondence to: William Wong, william .wong@ theta.utoronto.ca

CMAJ 2015. DOI:10.1503 /cmaj.140711
$\mathrm{T}$ he growing burden of chronic hepatitis $\mathrm{C}$ virus (HCV) infection poses a significant public health concern. A recent study of disease burden in Ontario ranked hepatitis $\mathrm{C}$ first among all infectious diseases. ${ }^{1}$ Managing chronic HCV infection is difficult because the disease is clinically silent in most of those affected. Patients in whom the infection goes unrecognized and untreated may present with late-stage disease, which has potentially fatal complications. These complications may be reduced by offering timely treatment. ${ }^{2}$

In the United States, recently revised screening recommendations suggest that those born between 1945 and 1965 should be screened. ${ }^{3}$ It would be helpful to ascertain whether these US recommendations would be cost-effective in Canada, given differences in epidemiology of the disease and in health care systems between the 2 countries. $^{2}$ The issue of cost is particularly salient because several new, effective but expensive regimens for treating chronic $\mathrm{HCV}$ infection are in development. ${ }^{4}$ The markedly im- proved tolerability of these new regimens and the anticipated high cure rates are likely to increase substantially both treatment uptake and overall treatment costs. However, higher efficacy may also lead to reduced downstream costs related to the complications of end-stage liver disease. The Public Health Agency of Canada is reviewing its hepatitis $\mathrm{C}$ screening guidance to determine whether expanded screening might reduce the number of undiagnosed infections. The objective of this study was to develop a model for projecting the health and economic effects of various 1-time screening strategies for chronic $\mathrm{HCV}$ infection for different populations within Canada.

\section{Methods}

\section{Study cohort}

We developed a state-transition model of $\mathrm{HCV}$ to assess the cost-effectiveness of alternative screening strategies for patients with chronic $\mathrm{HCV}$ mono-infection in Canada. 
We included individuals living in Canada at the time of the 2011 population census. Our baseline analyses considered 1-time screening for individuals 25-64 years of age or 45-64 years of age.

\section{Treatments considered}

We assumed that patients with chronic HCV infection who are offered antiviral therapy would be treated with pegylated interferon (peginterferon) plus ribavirin, simeprevir-based combination therapy, sofosbuvir-based combination therapy or ABT-450-based interferon-free combination therapy, according to Canadian guidelines or the results of phase 3 clinical trials. ${ }^{5-12}$ Peginterferon-ribavirin is currently funded by most drug plans in Canada. Simeprevir-based combination therapy has been approved by Health Canada and was recently recommended by the Canadian Agency for Drugs and Technologies in Health for treating genotype 1 infection. ${ }^{13}$ Sofosbuvir-based combination therapy has also been approved by Health Canada and was recommended by the Canadian Agency for Drugs and Technologies in Health for treating genotypes 1, 2 and 3 infection. ${ }^{14}$ ABT-450-based interferon-free combination therapy has recently completed phase 3 clinical trials ${ }^{11}$ and has not yet been approved by Health Canada.

\section{Screening strategies}

We considered 4 screening strategies for the baseline cost-effectiveness analysis.

No screening (status quo): We assumed that $69.5 \%(50 \%-85 \%$ in sensitivity analysis) of $\mathrm{HCV}$-infected patients are initially unaware of their infection and do not receive antiviral treatment. ${ }^{15} \mathrm{We}$ also assumed that each year $0.68 \%$ of these infected but unaware individuals discover their infection. ${ }^{16}$ Among those whose infection remains undetected, we assumed that liver disease is detected upon development of cirrhosis with liver failure and/or hepatocellular carcinoma.

Screen and treat with peginterferon-ribavirin: Individuals are offered 1-time screening for $\mathrm{HCV}$ infection by their primary care physician at a visit scheduled for another purpose (a "case-finding" strategy). Screening involves a blood test for $\mathrm{HCV}$ antibody. All tests with a positive antibody result will be followed by a test for HCV RNA to confirm the infection. In our analysis, we assumed that all individuals with positive results for both tests are referred to a hepatologist, gastroenterologist or infectious disease specialist and may be offered treatment with peginterferon-ribavirin, according to current Canadian guidelines. ${ }^{5}$

Screen and treat with peginterferon-ribavirin- based direct-acting antiviral agents: We used the same assumptions as outlined for the second strategy (screen and treat with peginterferonribavirin). Here, however, we assumed that patients with genotype 1 infection will be offered simeprevir-based combination therapy, ${ }^{8,9}$ patients with genotype 2 or 3 infection will be offered sofosbuvir-based combination therapy, ${ }^{7,12}$ and patients with any other genotypes will be offered peginterferon-ribavirin. ${ }^{5}$

Screen and treat with interferon-free directacting antiviral agents: We used the same assumptions as outlined for the third strategy (see above), except we assumed that patients with genotype 1 infection will be offered interferon-free therapy (i.e., ABT-450-based interferon-free combination therapy). ${ }^{10,11}$

\section{Decision model}

We developed a cohort-based, state-transition model using TreeAge Pro 2013 software ${ }^{17}$ In our simulations, cohort members moved between predefined health states in weekly cycles until all members had died. Health states are shown in Figure 1 and allowable transitions among health states in Appendix 1 (available at www.cmaj.ca /lookup/suppl/doi:10.1503/cmaj.140711/-/DC1).

\section{Model parameters}

We obtained model parameters (listed in Table 1 and Table 2), including disease progression parameters, probabilities of transition to advanced liver disease, mortality rates, treatment-related efficacy, epidemiologic variables and direct medical costs, from the literature ${ }^{7-16,18-59}$ (refer to Appendix 2, available at www.cmaj.ca/lookup /suppl/doi:10.1503/cmaj.140711/-/DC1 for detailed descriptions of these parameters). We obtained utility data for various health states from the most recent and valid Canadian utility study available, published by Hsu and colleagues ${ }^{47}$ in 2012 and based on the Health Utilities Index Mark 2. That study included 700 patients across different chronic HCV infection health states.

\section{Economic assumptions}

We conducted our analysis from the payer's perspective and structured it as a cost-utility analysis, with outcomes expressed in terms of quality-adjusted life-years (QALYs) and costs. Future costs and health benefits were discounted at $5 \%$ annually. ${ }^{58}$

\section{Results}

\section{Model validation}

For validation purposes, we ran our model using the baseline parameter values. As shown in 
Appendix 3 (available at www.cmaj.ca/lookup /suppl/doi:10.1503/cmaj.140711/-/DC1), we compared the predicted outcomes of our model against data reported in other studies. ${ }^{57,60,61}$ These outcomes included probability of progression to cirrhosis and probability of liver-related death. The results of our model closely matched the results of the other studies. . $^{57,60,61}$

\section{Base case}

In our baseline analysis for individuals 25-64 years old (Table 3 ), the screen-and-treat strategies were more costly but also more effective than no screening. According to the baseline model, for every 10000 people screened, about $63 \mathrm{HCV}$ cases would be identified, and 37 (59\%) of these patients would be eligible for treatment.

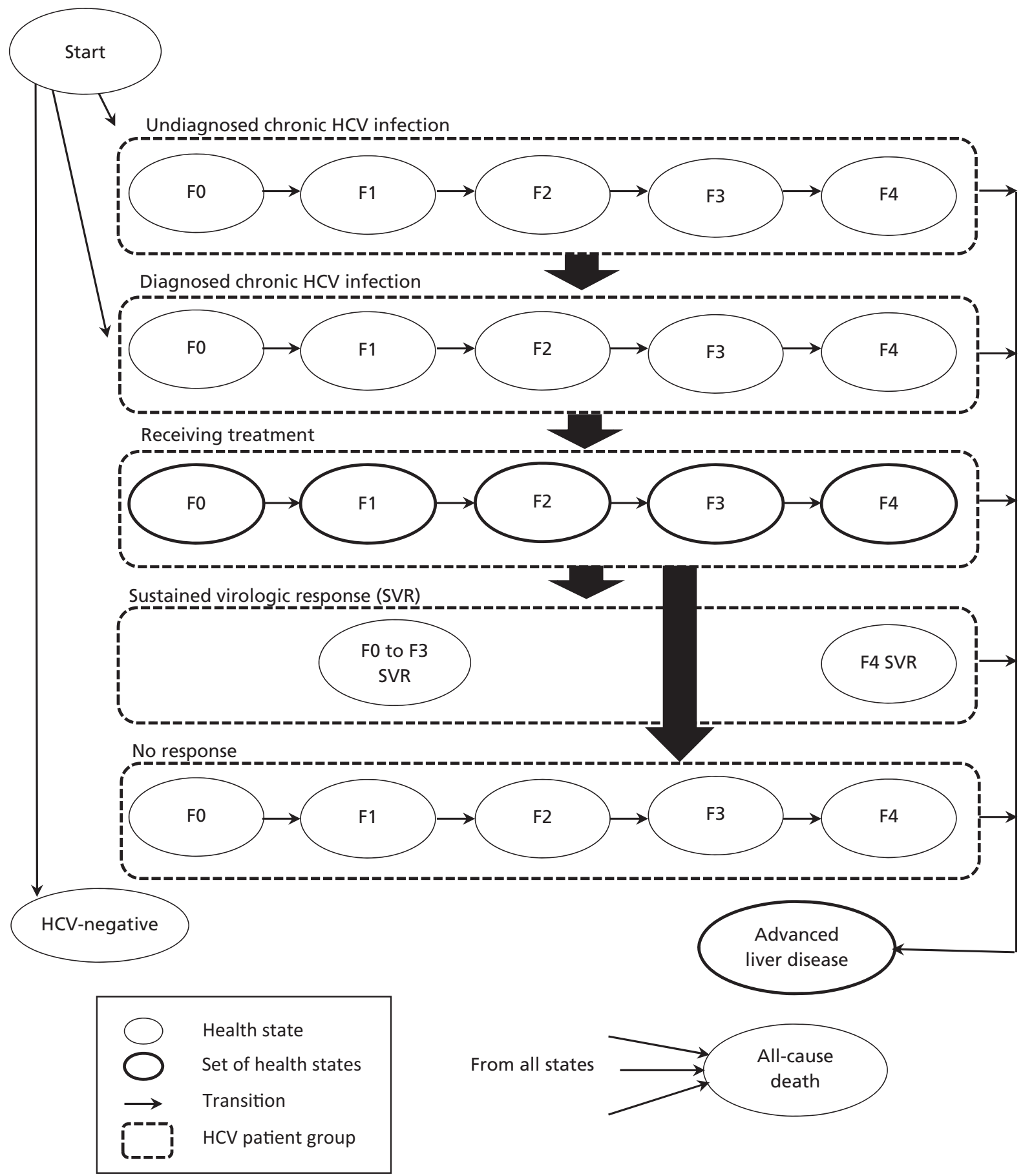

Figure 1: State-transition model of hepatitis C virus (HCV) infection and progression. For more detail about sets of health states, see Appendix 1 (available at www.cmaj.ca/lookup/suppl/doi:10.1503/cmaj.140711/-/DC1). F1-F4 = fibrosis stages. 
Table 1 (part 1 of 2): Treatment-related variables used in the model

\begin{tabular}{|c|c|c|c|}
\hline Variable & \multicolumn{2}{|c|}{ Parameter estimate (range) } & Source or reference no. \\
\hline \multicolumn{4}{|c|}{ Probability of receiving treatment, by fibrosis stage and viral genotype } \\
\hline \multicolumn{4}{|l|}{ Fibrosis stage 0} \\
\hline Genotype 1 & 0.37 & $(0.28-0.46)$ & TWH medical records \\
\hline Genotype 2 or 3 & 0.47 & $(0.35-0.59)$ & TWH medical records \\
\hline Genotype 4,5 or 6 & 0.5 & $(0.38-0.63)$ & TWH medical records \\
\hline \multicolumn{4}{|l|}{ Fibrosis stage 1} \\
\hline Genotype 1 & 0.5 & $(0.38-0.63)$ & TWH medical records \\
\hline Genotype 2 or 3 & 0.66 & $(0.50-0.83)$ & TWH medical records \\
\hline Genotype 4,5 or 6 & 0.5 & $(0.38-0.63)$ & TWH medical records \\
\hline \multicolumn{4}{|l|}{ Fibrosis stage 2} \\
\hline Genotype 1 & 0.5 & $(0.38-0.63)$ & TWH medical records \\
\hline Genotype 2 or 3 & 0.66 & $(0.50-0.83)$ & TWH medical records \\
\hline Genotype 4,5 or 6 & 0.5 & $(0.38-0.63)$ & TWH medical records \\
\hline \multicolumn{4}{|l|}{ Fibrosis stage 3} \\
\hline Genotype 1 & 0.55 & $(0.41-0.69)$ & TWH medical records \\
\hline Genotype 2 or 3 & 0.68 & $(0.51-0.85)$ & TWH medical records \\
\hline Genotype 4,5 or 6 & 0.5 & $(0.38-0.63)$ & TWH medical records \\
\hline \multicolumn{4}{|l|}{ Fibrosis stage 4} \\
\hline Genotype 1 & 0.63 & $(0.47-0.79)$ & TWH medical records \\
\hline Genotype 2 or 3 & 0.62 & $(0.47-0.78)$ & TWH medical records \\
\hline Genotype 4,5 or 6 & 0.61 & $(0.46-0.76)$ & TWH medical records \\
\hline \multicolumn{4}{|c|}{ Variables for treatment-naive cohort } \\
\hline \multicolumn{4}{|c|}{ Simeprevir-based combination therapy for genotype 1} \\
\hline \multicolumn{4}{|c|}{ Sustained virologic response rate } \\
\hline Fibrosis stage $0-2$ & 0.84 & $(0.81-0.87)$ & 8,9 \\
\hline Fibrosis stage 3 or 4 & 0.68 & $(0.64-0.72)$ & 8,9 \\
\hline Discontinuation rate & 0.156 & $(0.117-0.195)$ & 8,9 \\
\hline Virologic response rate* & 0.859 & $(0.64-1.00)$ & 8,9 \\
\hline \multicolumn{4}{|l|}{ Adverse events } \\
\hline Anemia & 0.21 & $(0.18-0.24)$ & 8,9 \\
\hline Depression & 0.12 & $(0.06-0.21)$ & 8,9 \\
\hline Pruritus & 0.26 & $(0.21-0.32)$ & 8,9 \\
\hline Rash & 0.29 & $(0.25-0.32)$ & 8,9 \\
\hline \multicolumn{4}{|c|}{ ABT-450-based combination therapy for genotype 1} \\
\hline \multicolumn{4}{|c|}{ Sustained virologic response rate } \\
\hline Fibrosis stage $0-3$ & 0.96 & $(0.945-0.979)$ & 11 \\
\hline Fibrosis stage 4 & 0.94 & $(0.892-0.991)$ & 10 \\
\hline \multicolumn{4}{|l|}{ Discontinuation rate } \\
\hline Fibrosis stage $0-3$ & 0.01 & $(0.008-0.013)$ & 11 \\
\hline Fibrosis stage 4 & 0.02 & $(0.02-0.03)$ & 10 \\
\hline \multicolumn{4}{|l|}{ Adverse events } \\
\hline Anemia & 0.08 & $(0.06-0.10)$ & 10 \\
\hline Depression & 0.01 & $(0.01-0.01)$ & 10 \\
\hline Pruritus & 0.11 & $(0.08-0.14)$ & 10 \\
\hline Rash & 0.18 & $(0.14-0.23)$ & 10 \\
\hline \multicolumn{4}{|c|}{ Pegylated interferon + ribavirin therapy } \\
\hline \multicolumn{4}{|l|}{ Genotype 1} \\
\hline \multicolumn{4}{|c|}{ Sustained virologic response rate } \\
\hline Fibrosis stage $0-2$ & 0.49 & $(0.44-0.53)$ & $18-31$ \\
\hline Fibrosis stage 3 or 4 & 0.37 & $(0.30-0.43)$ & $18-31$ \\
\hline Discontinuation rate & 0.38 & $(0.34-0.42)$ & $18-31$ \\
\hline \multicolumn{4}{|l|}{ Adverse events } \\
\hline Anemia & 0.22 & $(0.19-0.26)$ & $20-30$ \\
\hline Depression & 0.22 & $(0.19-0.26)$ & $20-30$ \\
\hline Pruritus & 0.26 & $(0.22-0.30)$ & $20-30$ \\
\hline Rash & 0.25 & $(0.22-0.29)$ & $20-30$ \\
\hline
\end{tabular}


Identifying these 37 cases and treating them would prevent $9 \mathrm{HCV}$-related deaths if peginterferon-ribavirin were used for treatment or 18 HCV-related deaths if direct-acting antiviral therapy were used over the lifetime of the cohort (Table 4). As such, the number of individuals that would have to be screened to prevent 1 HCV-related death would be 1112 (10000/9) if peginterferon-ribavirin were used for treatment or $556(10000 / 18)$ if direct-acting antiviral therapy were used for treatment.

In the model, when peginterferon-ribavirin was used for treatment, the screen-and-treat strategy increased life expectancy for the whole population (by 0.0119 life-years) and especially for patients with chronic HCV infection (by 2.06 life-years). The health benefit was 0.0032 QALYs per person screened (1.2 qualityadjusted days). Screening increased HCV-related costs by $\$ 124$ per person, which resulted in an incremental cost-effectiveness ratio of $\$ 38117$ per QALY gained, relative to no screening (Table 3).

Use of peginterferon-ribavirin-based directacting antiviral (i.e., simeprevir) for treatment increased life expectancy by 0.0202 life-years

\begin{tabular}{|c|c|c|c|}
\hline \multirow{2}{*}{$\begin{array}{l}\text { Variable } \\
\text { Genotype } 2 \text { or } 3\end{array}$} & \multicolumn{2}{|c|}{ Parameter estimate (range) } & \multirow[t]{2}{*}{ Source or reference no. } \\
\hline & & & \\
\hline Sustained virologic response rate & 0.77 & $(0.71-0.82)$ & $32-38$ \\
\hline Discontinuation rate $\ddagger$ & 0.09 & $(0.06-0.13)$ & $32-38$ \\
\hline \multicolumn{4}{|l|}{ Adverse events } \\
\hline Anemia & 0.12 & $(0.03-0.39)$ & $32,34,36,38$ \\
\hline Depression & 0.19 & $(0.12-0.28)$ & $32,34,36,38$ \\
\hline Pruritus & 0.24 & $(0.14-0.39)$ & $32,34,36,38$ \\
\hline Rash & 0.24 & $(0.14-0.39)$ & $32,34,36,38$ \\
\hline \multicolumn{4}{|l|}{ Genotype 4,5 or $6 \S$} \\
\hline Sustained virologic response ratet & 0.65 & $(0.57-0.71)$ & $39-41$ \\
\hline Discontinuation ratet & 0.38 & $(0.34-0.42)$ & $20-30$ \\
\hline \multicolumn{4}{|l|}{ Adverse events } \\
\hline Anemia & 0.22 & $(0.19-0.26)$ & $20-30$ \\
\hline Depression & 0.22 & $(0.19-0.26)$ & $20-30$ \\
\hline Pruritus & 0.26 & $(0.22-0.30)$ & $20-30$ \\
\hline Rash & 0.25 & $(0.22-0.29)$ & $20-30$ \\
\hline \multicolumn{4}{|c|}{ Sofosbuvir-based combination therapy } \\
\hline \multicolumn{4}{|l|}{ Genotype 2} \\
\hline \multicolumn{4}{|l|}{ Sustained virologic response rate } \\
\hline Fibrosis stage $0-3$ & 0.967 & $(0.828-0.999)$ & 7 \\
\hline Fibrosis stage 4 & 1 & $(0.158-1.000)$ & 7 \\
\hline Discontinuation rate & 0 & $(0.00-0.02)$ & 7 \\
\hline \multicolumn{4}{|l|}{ Adverse events } \\
\hline Anemia & 0.08 & $(0.06-0.10)$ & 12 \\
\hline Depression & 0.055 & $(0.04125-0.06875)$ & 12 \\
\hline Pruritus & 0.07 & $(0.0525-0.0875)$ & 12 \\
\hline Rash & 0.09 & $(0.0675-0.1125)$ & 12 \\
\hline \multicolumn{4}{|l|}{ Genotype 3} \\
\hline \multicolumn{4}{|l|}{ Sustained virologic response rate } \\
\hline Fibrosis stage $0-3$ & 0.946 & $(0.863-0.976)$ & 7 \\
\hline Fibrosis stage 4 & 0.923 & $(0.640-0.998)$ & 7 \\
\hline Discontinuation rate & 0.016 & $(0.012-0.020)$ & 7 \\
\hline \multicolumn{4}{|l|}{ Adverse events } \\
\hline Anemia & 0.08 & $(0.06-0.10)$ & 12 \\
\hline Depression & 0.055 & $(0.04125-0.06875)$ & 12 \\
\hline Pruritus & 0.09 & $(0.0675-0.1125)$ & 7 \\
\hline Rash & 0.27 & $(0.2025-0.3375)$ & 12 \\
\hline \multicolumn{4}{|c|}{$\begin{array}{l}\text { Note: TWH = Toronto Western Hospital, University Health Network, Toronto, Ont. } \\
\text { *Eligible for short therapy. } \\
\text { †Standard algorithm; } 48 \text {-wk treatment. } \\
\text { ‡Standard algorithm; } 24 \text {-wk treatment. } \\
\text { §Data used here are based on genotype } 4 .\end{array}$} \\
\hline
\end{tabular}


for the entire baseline population or 3.50 lifeyears for those with chronic HCV infection. Compared with no screening, this form of treatment resulted in a net cost increment of \$267 and 0.0063 QALYs gained per person, which translated to an incremental cost-effectiveness ratio of \$42398 per QALY gained (Table 3).
Use of interferon-free direct-acting antiviral (i.e., ABT-450-based combination therapy) for treatment, assuming a cost of $\$ 50000$ per treatment course, increased life expectancy by 0.0226 life-years for the entire baseline population or 4.18 life-years for those with chronic HCV infection. Compared with no screening, this

Table 2: Costs and utilities used in the model

Cost or utility Parameter estimate (range) Refence no.

\section{Costs, \$}

Transplant

121732

(91299-152 165)

42

Post-transplant care

17976

(13482-22470)

42

Antiviral therapy, by algorithm

Simeprevir-based combination therapy

46157

(34618-57696)

13

(24-wk pegylated interferon +

ribavirin)

Simeprevir-based combination therapy

55811

(41858-69764)

13

(48-wk pegylated interferon + ribavirin)

Sofosbuvir-based combination therapy (12 wk)

55000

(41 250-68750)

13

ABT-450-based combination therapy

50000

Pegylated interferon + ribavirin, 48 wk

19948

(40000-62500)

Pegylated interferon + ribavirin, 24 wk

9974

(14961-24935)

Assumed

Adverse event, wkly

Anemia

107

(7481-12467)

14

Depression

107
73

(80-134)

(55-91)

43

Pruritus

Rash

12

(9-15)

$\frac{(9-15)}{(10.86-18.10)}$

Anti-HCV test

12

14.48

(75-125)

HCV RNA test

100

(75-125)

\section{Utilities}

Age, mean for Canadian population, yr

$\begin{array}{llll}25-34 & 0.90 & (0.89-0.92) & 45,46 \\ 35-44 & 0.88 & (0.86-0.91) & 45,46 \\ 45-54 & 0.86 & (0.83-0.88) & 45,46 \\ 55-64 & 0.83 & (0.80-0.87) & 45,46\end{array}$

Utility for health states related to chronic HCV infection

\begin{tabular}{|c|c|c|c|}
\hline Non-cirrhosis (fibrosis stage $0-3$ ) & 0.73 & $(0.69-0.77)$ & 47 \\
\hline $\begin{array}{l}\text { Compensated cirrhosis (fibrosis } \\
\text { stage 4) }\end{array}$ & 0.69 & $(0.65-0.73)$ & 47 \\
\hline Hepatocellular carcinoma & 0.72 & $(0.68-0.75)$ & 47 \\
\hline Decompensated cirrhosis* & 0.65 & $(0.65-0.73)$ & 47,48 \\
\hline Post-transplant & 0.75 & $(0.70-0.79)$ & 47 \\
\hline Viral clearance & 0.80 & $(0.76-0.84)$ & 47 \\
\hline On treatment & 0.71 & $(0.67-0.75)$ & 47 \\
\hline
\end{tabular}

Note: $\mathrm{HCV}=$ hepatitis $\mathrm{C}$ virus.

*The study ${ }^{47}$ did not include patients with decompensated cirrhosis, so utility for these patients was determined by adjusting the chronic HCV infection utility score according to a disutility value published in the systematic review. ${ }^{48}$ 
approach resulted in a net cost increment of \$266 and 0.0077 QALYs gained per person, which translated to an incremental cost-effectiveness ratio of \$34783 per QALY gained (Table 3).

We repeated the 4 screening strategies by considering 1-time screening for individuals 45-64 years of age. The results (Table 3) showed that it would also be cost-effective to screen and treat patients with chronic HCV infection in this age group, with incremental cost-effectiveness ratios of $\$ 34359$ per QALY for treatment with peginterferon-ribavirin, \$35562 per QALY for treatment with interferonfree direct-acting antiviral therapy and $\$ 44034$ per QALY for treatment with peginterferonribavirin-based direct-acting antiviral therapy, relative to no screening.

\section{Scenario analyses}

We conducted various scenario analyses to examine the cost-effectiveness of the screening program under different assumptions (where scenario analyses involve assumptions other than those used for the base-case analysis, usually with adjustments to multiple parameters simultaneously). In these scenario analyses, we repeated the 4 screening strategies with different age ranges (Appendix 4, available at www.cmaj.ca /lookup/suppl/doi:10.1503/cmaj.140711/-/DC1), different treatment patterns (Appendix 5, available at www.cmaj.ca/lookup/suppl/doi:10.1503 /cmaj.140711/-/DC1) and restricted treatment (Appendix 6, available at www.cmaj.ca/lookup /suppl/doi:10.1503/cmaj.140711/-/DC1).

In our baseline analysis, we assumed that the probability of being treated anywhere in Canada was similar to that at a single tertiary care hospital (Toronto Centre for Liver Disease, Toronto Western Hospital, University Health Network, Toronto, Ontario). Under this assumption, the incremental cost-effectiveness ratio for treatment with interferon-free direct-acting antiviral therapy was $\$ 34783$ per QALY, compared with no screening. To estimate future treatment patterns for patients with chronic HCV infection, we surveyed physicians treating such patients in Ontario

Table 3: Baseline cost-effectiveness results

\begin{tabular}{|c|c|c|c|c|c|c|}
\hline \multirow[b]{2}{*}{ Strategy } & \multicolumn{5}{|c|}{ Comparison with common baseline (no screening) } & \multirow{2}{*}{$\begin{array}{l}\text { Sequential } \\
\text { ICER, \$ }\end{array}$} \\
\hline & Cost, $* \$$ & QALYs & $\Delta$ Cost, $\$$ & $\triangle \mathrm{QALYs}$ & ICER, \$ & \\
\hline \multicolumn{7}{|l|}{ Age 25-64 yr } \\
\hline No screening & 71327 & 13.7653 & - & - & - & - \\
\hline $\begin{array}{l}\text { Screen and treat with } \\
\text { PEG IFN+RBV }\end{array}$ & 71450 & 13.7685 & 124 & 0.0032 & $38117 \dagger$ & $38117 \dagger$ \\
\hline $\begin{array}{l}\text { Screen and treat with } \\
\text { interferon-free DAA (G1), } \\
\text { SOF+RBV (G2/3) or } \\
\text { PEG IFN+RBV (G4/5/6) }\end{array}$ & 71593 & 13.7729 & 266 & 0.0077 & 34783 & 34783 \\
\hline $\begin{array}{l}\text { Screen and treat with } \\
\text { simeprevir + PEG IFN+RBV } \\
\text { (G1), SOF+RBV (G2/3) or } \\
\text { PEG IFN+RBV (G4/5/6) }\end{array}$ & 71593 & 13.7716 & 267 & 0.0063 & 42398 & Dominated \\
\hline \multicolumn{7}{|l|}{ Age 45-64 yr } \\
\hline No screening & 83335 & 12.1027 & - & - & - & - \\
\hline $\begin{array}{l}\text { Screen and treat with } \\
\text { PEG IFN+RBV }\end{array}$ & 83476 & 12.1068 & 141 & 0.0041 & 34359 & 34359 \\
\hline $\begin{array}{l}\text { Screen and treat with } \\
\text { simeprevir + PEG IFN+RBV } \\
\text { (G1), SOF+RBV (G2/3) or } \\
\text { PEG IFN+RBV (G4/5/6) }\end{array}$ & 83672 & 12.1104 & 337 & 0.0077 & 44034 & $55151+$ \\
\hline $\begin{array}{l}\text { Screen and treat with } \\
\text { interferon-free DAA (G1), } \\
\text { SOF+RBV (G2/3) or } \\
\text { PEG IFN+RBV (G4/5/6) }\end{array}$ & 83673 & 12.1122 & 338 & 0.0095 & 35562 & 36471 \\
\hline
\end{tabular}


for their treatment preferences among antiviral regimens expected to be available in Canada in the next 5 years. The survey results indicated that the treatment rate for treatment-naive patients would be $87.5 \%$, provided interferonfree direct-acting antiviral was available (unpublished data). In this scenario analysis (Appendix 5), using a probability of treatment of $87.5 \%$ for patients with genotype 1,2 or 3 , the incremental cost-effectiveness ratio with interferon-free direct-acting antiviral treatment declined from \$34783 to \$28459 per QALY, compared with no screening.

The Canadian Agency for Drugs and Technologies in Health has recommended that treatment be limited to patients with fibrosis stages 2 to $4 .{ }^{13}$ In this scenario analysis (Appendix 6), with treatment limited to patients with fibrosis stages 2 to 4 , the incremental cost-effectiveness ratios increased as follows: from $\$ 38117$ to $\$ 47466$ per QALY for screening and treatment with peginterferon-ribavirin, from $\$ 42398$ to $\$ 47573$ per QALY for screening and treatment with peginterferon-ribavirin-based direct-acting antiviral therapy, and from $\$ 34783$ to $\$ 38298$ per QALY for screening and treatment with interferon-free direct-acting antiviral therapy.

Most of the scenario analyses indicated that it would be cost-effective to screen and treat patients with chronic $\mathrm{HCV}$ infection in the age range 25-64 years old or 45-64 years old.

\section{Sensitivity analyses}

We performed both 1-way deterministic sensitivity analyses and probabilistic sensitivity analyses, using the same assumptions as the base-case analysis, to explore the effect of uncertainty of the model's parameters.

For the deterministic sensitivity analyses, Appendix 7 (available at www.cmaj.ca/lookup /suppl/doi:10.1503/cmaj.140711/-/DC1) summarizes the effects of varying the parameters related to chronic HCV infection, to screening and to treatment, with use of tornado diagrams to examine the cost-effectiveness of screening.

Varying parameters related to chronic $\mathrm{HCV}$ infection, such as costs (excluding the cost of antiviral therapy) and utilities, had the largest

Table 4: Health events with various strategies*

\begin{tabular}{|c|c|c|c|c|}
\hline \multirow[b]{2}{*}{ Screening strategy } & \multicolumn{3}{|c|}{ Health event; no. per 10000 screened $\dagger$} & \multirow[b]{2}{*}{$\begin{array}{l}\text { HCV-related deaths } \\
\text { prevented v. "no } \\
\text { screening" }\end{array}$} \\
\hline & $\begin{array}{c}\text { Decompensated } \\
\text { cirrhosis }\end{array}$ & $\begin{array}{l}\text { Hepato- } \\
\text { cellular } \\
\text { carcinoma }\end{array}$ & $\begin{array}{c}\text { HCV-related liver } \\
\text { death }\end{array}$ & \\
\hline \multicolumn{5}{|l|}{ Age 25-64 yr } \\
\hline No screening & 24 & 15 & 35 & - \\
\hline Screen and treat with PEG IFN+RBV & 18 & 12 & 26 & 9 \\
\hline $\begin{array}{l}\text { Screen and treat with } \\
\text { simeprevir + PEG IFN+RBV (G1), } \\
\text { SOF+RBV (G2/3) or PEG IFN+RBV (G4/5/6) }\end{array}$ & 14 & 7 & 18 & 18 \\
\hline $\begin{array}{l}\text { Screen and treat with interferon-free } \\
\text { DAA (G1), SOF+RBV }(G 2 / 3) \text { or } \\
\text { PEG IFN+RBV }(G 4 / 5 / 6)\end{array}$ & 13 & 7 & 18 & 18 \\
\hline \multicolumn{5}{|l|}{ Age 45-64 yr } \\
\hline No screening & 29 & 20 & 44 & - \\
\hline Screen and treat with PEG IFN+RBV & 23 & 17 & 35 & 9 \\
\hline $\begin{array}{l}\text { Screen and treat with } \\
\text { simeprevir + PEG IFN+RBV (G1), } \\
\text { SOF+RBV (G2/3) or PEG IFN+RBV (G4/5/6) }\end{array}$ & 20 & 8 & 24 & 20 \\
\hline $\begin{array}{l}\text { Screen and treat with interferon-free } \\
\text { DAA (G1), SOF+RBV (G2/3) or } \\
\text { PEG IFN+RBV }(G 4 / 5 / 6)\end{array}$ & 18 & 8 & 23 & 21 \\
\hline \multicolumn{5}{|c|}{ 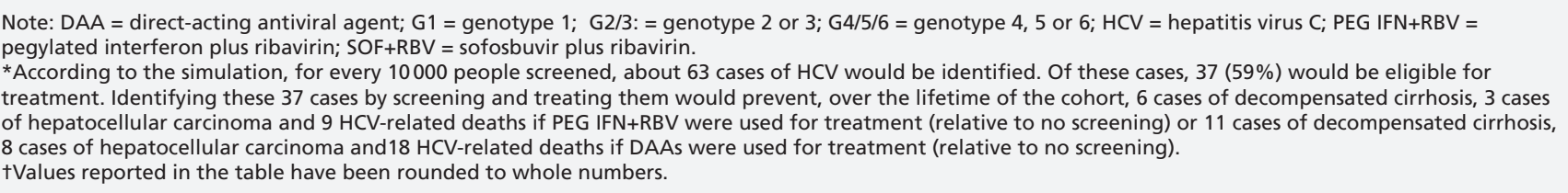 } \\
\hline
\end{tabular}


effect on the main results. The incremental costeffectiveness ratio generated from these sensitivity analyses for screening and treatment with peginterferon-ribavirin ranged from $\$ 18264$ to \$39780 per QALY.

When we varied screening-related parameters, such as prevalence, screening acceptance rate, known HCV infection rate and cost of screening, the incremental cost-effectiveness ratio generated by screening and treatment with peginterferonribavirin ranged from $\$ 34108$ to $\$ 52693$ per QALY. In the sensitivity analysis on prevalence (see Appendix 8, available at www.cmaj.ca /lookup/suppl/doi:10.1503/cmaj.140711/-/DC1), the incremental cost-effectiveness ratio generated with screening and treatment with peginterferonribavirin remained under $\$ 50000$ as long as the prevalence was greater than $0.2 \%$. For the parameter related to known HCV infection (see Appendix 7), the incremental cost-effectiveness ratio generated by screening and treatment remained under $\$ 50000$ for infection rates ranging from $15.7 \%$ to $50.7 \% .^{15}$

According to our probabilistic sensitivity analyses, the chance that screening and treatment would cost less than $\$ 50000$ per QALY (relative to no screening) was $56 \%$ for peginterferonribavirin, $51 \%$ for peginterferon-ribavirinbased direct-acting antiviral therapy and $60 \%$ for interferon-free direct-acting antiviral therapy. The chance that screening and treatment would cost less than $\$ 100000$ per QALY was $71 \%$ for peginterferon-ribavirin, $76 \%$ for peginterferon-ribavirin-based direct-acting antiviral therapy and $77 \%$ for interferon-free direct-acting antiviral therapy (Appendix 9, available at www.cmaj.ca/lookup/suppl/doi:10 .1503/cmaj.140711/-/DC1).

\section{Exploratory analysis}

The price of interferon-free direct-acting antiviral therapy was unknown, so we conducted a threshold analysis to explore what the treatment costs would have to be for screening and treatment to be considered cost-effective under different willingness-to-pay thresholds (Appendix 10, available at www.cmaj.ca/lookup/suppl/doi :10.1503/cmaj.140711/-/DC1). We found that the incremental cost-effectiveness of screening and treatment with interferon-free direct-acting antivirals as first-line therapy would remain below $\$ 50000$ per QALY, relative to no screening, if a single course of therapy cost less than $\$ 112145$. At a willingness-to-pay threshold of $\$ 100000$ per QALY, screening and treatment with interferon-free direct-acting antivirals as first-line therapy would remain cost-effective if the cost of therapy was less than $\$ 310262$.

\section{Interpretation}

Our baseline analysis suggested that a selective, 1-time hepatitis $\mathrm{C}$ screening program in Canada for individuals aged 25-64 years or 45-64 years would prevent at least $9 \mathrm{HCV}$-related deaths per 10000 persons over the lifetime of the cohort and is likely to be cost-effective, at $\$ 34359$ to $\$ 44034$ per QALY gained. The conventional upper limit of applied cost-effectiveness thresholds $^{50-52}$ varies among countries, from $\$ 50000$ to $\$ 120000$ per QALY. The results of multiple 1-way deterministic and probabilistic sensitivity analyses provided evidence that the screen-andtreat approach is likely to be cost-effective, taking into consideration the uncertainty of the model's parameters.

Published studies from the US have reported incremental cost-effectiveness ratios ranging from Can $\$ 18800$ to Can $\$ 90000$ per QALY for birth cohort screening and treatment with peginterferon-ribavirin or peginterferon-ribavirinbased direct-acting antiviral therapy. For example, Rein and associates ${ }^{50}$ reported an incremental cost-effectiveness ratio of US\$15429 per QALY for universal screening and treatment with peginterferon-ribavirin and US $\$ 31100$ per QALY for screening and treatment with telaprevir-based combination therapy. Eckman and colleagues $^{62}$ showed that it was cost-effective to screen for HCV and treat with boceprevir according to US guidelines (US\$47276 per QALY). Liu and associates ${ }^{63}$ reported incremental costeffectiveness ratios of US\$73228 per QALY for universal birth cohort screening and treatment with peginterferon-ribavirin and US\$59835 per QALY for universal birth cohort screening and treatment with boceprevir. The authors of most of these studies concluded that it would be costeffective to offer 1-time screening for Americans born between 1945 and 1965. In part because of these findings, the US Centers for Disease Control and Prevention has, since August 2012, recommended 1-time testing for persons born from 1945 to $1965 .^{3}$

The Public Health Agency of Canada is now reviewing its screening guidance for $\mathrm{HCV}$. Public health policy should be informed by consideration of health benefits, social and ethical values, feasibility and cost-effectiveness. Our analysis will assist in the development of HCV screening guidance by informing the last of these criteria. We believe that it offers scientifically valid projections based largely on Canadian data.

In Canada, the treatment uptake rate is low. In 2008, Sherman ${ }^{64}$ estimated that only 20000 to 30000 HCV-infected individuals in Canada had been treated over the 15 years that treatment had been available. The adverse effects of peginter- 
feron-ribavirin therapy have been identified as a barrier to treatment uptake. ${ }^{64,65}$ The main adverse effects associated with peginterferon-ribavirin therapy are anemia, depression, rash, pruritus and flu-like symptoms. The peginterferon-ribavirinbased direct-acting antiviral simeprevir has substantially fewer of these adverse effects. ${ }^{13}$ Phase 3 trials with interferon-free direct-acting antiviral therapy ${ }^{10,11,66-69}$ have shown high rates of sustained virologic response with no resistance or major adverse events in most populations. The interferon-free drugs are administered orally, and thus are tolerable, safe and convenient for patients. Uptake will likely increase when more interferon-free drugs become available. The results of our scenario analyses suggest that the screen-and-treat strategy is likely to remain costeffective if uptake is increased to $87.5 \%$.

\section{Limitations}

Our analysis had some limitations. We may have overestimated adherence to therapy and underestimated the discontinuation rate relative to real clinical settings. In addition, the number of patients with cirrhosis in the trials was limited, which increases the uncertainty of treatment efficacy for this important population. Our analysis also assumed that the probability of being treated and the distribution of fibrosis stages for patients with chronic HCV infection in Canada were similar to those at a single tertiary care hospital (Toronto Western Hospital, University Health Network). In addition, similar to other published cohort simulation studies, ${ }^{50,62,63}$ our analysis did not implicitly implement the time from diagnosis to treatment. Thus, the analyses cannot capture the full benefits or limitations for the time from diagnosis to treatment. We also did not consider every possible screening strategy. For example, we did not investigate the economic benefit of screening high-risk groups such as immigrants from high-burden countries, emergency department or in-hospital populations, skin-piercing practitioners or low-income groups. Recent studies in the US have shown that populations such as patients undergoing hemodialysis, ${ }^{70}$ health care professionals, ${ }^{71,72}$ skin-piercing practitioners $^{73}$ and low-income groups ${ }^{74}$ have contributed substantially to the overall prevalence of chronic HCV infection in that country. Screening for chronic $\mathrm{HCV}$ infection within these high-risk groups in Canada could be explored as an alternative strategy.

\section{Conclusion}

Our analyses suggest that in Canada, a 1-time program to screen for and treat $\mathrm{HCV}$ infection, aimed at birth cohort populations (25-64 or
45-64 years of age), is likely to be cost-effective. The screening programs that we evaluated would identify people with chronic $\mathrm{HCV}$ infection who are asymptomatic, which would in turn allow medical treatment to be offered, if needed, according to published guidelines, ideally before development of advanced liver disease. Early recognition of infected individuals and linkage of these people with care, treatment, alcohol and other lifestyle counselling, and other forms of support could reduce the large pool of undiagnosed HCV infections, save and prolong the lives of people with such infections, and avert the lengthy hospital stays and costs associated with HCV-related end-stage liver disease, liver transplant and hepatocellular carcinoma.

\section{References}

1. Kwong JC, Crowcroft NS, Campitelli MS, et al. Ontario burden of infectious disease study. Toronto: Institute for Clinical Evaluative Sciences; 2010.

2. Shah HA, Heathcote EJ, Feld JJ. A Canadian screening program for hepatitis C: Is now the time? CMAJ 2013;185:1325-8.

3. Recommendations for the identification of chronic hepatitis $\mathrm{C}$ virus infection among persons born during 1945-1965. MMWR Recomm Rep 2012;(RR-4):1-32. Erratum in: MMWR Recomm Rep 2012;61:886.

4. Asselah T, Marcellin P. Direct acting antivirals for the treatment of chronic hepatitis C: one pill a day for tomorrow. Liver Int 2012;32 Suppl 1:88-102.

5. Sherman M, Shafran S, Burak K, et al. Management of chronic hepatitis C: consensus guidelines. Can J Gastroenterol 2007;21 Suppl C:25C-34C

6. Myers RP, Ramji A, Bilodeau M, et al. An update on the management of hepatitis $\mathrm{C}$ : consensus guidelines from the Canadian Association for the Study of the Liver. Can J Gastroenterol 2012;26:359-75

7. Zeuzem S, Dusheiko GM, Salupere R, et al. Sofosbuvir and ribavirin in HCV genotypes 2 and 3. N Engl J Med 2014;370:19932001.

8. Manns M, Marcellin P, Poordad F, et al. Simeprevir with pegylated interferon alfa $2 \mathrm{a}$ or $2 \mathrm{~b}$ plus ribavirin in treatmentnaive patients with chronic hepatitis $\mathrm{C}$ virus genotype 1 infection (QUEST-2): a randomised, double-blind, placebocontrolled phase 3 trial. Lancet 2014;384:414-26.

9. Jacobson IM, Dore GJ, Foster GR, et al. Simeprevir with pegylated interferon alfa 2 a plus ribavirin in treatment-naive patients with chronic hepatitis $\mathrm{C}$ virus genotype 1 infection (QUEST-1): a phase 3, randomised, double-blind, placebocontrolled trial. Lancet 2014;384:403-13.

10. Poordad F, Hezode C, Trinh R, et al. ABT-450/r-Ombitasvir and dasabuvir with ribavirin for hepatitis $\mathrm{C}$ with cirrhosis. $N$ Engl J Med 2014;370:1973-82.

11. Feld JJ, Kowdley KV, Coakley E, et al. Treatment of HCV with ABT-450/r-ombitasvir and dasabuvir with ribavirin. $N$ Engl J Med 2014;370:1594-603.

12. Lawitz E, Mangia A, Wyles D, et al. Sofosbuvir for previously untreated chronic hepatitis C infection. $N$ Engl $\mathrm{J} \mathrm{Med}$ 2013;368:1878-87.

13. CADTH therapeutic review: direct-acting antiviral agents for chronic hepatitis $\mathrm{C}$ genotype 1. Ottawa: Canadian Agency for Drugs and Technologies in Health; 2014

14. Common drug review drug database. Ottawa: Canadian Agency for Drugs and Technologies in Health. Available: www.cadth .ca/en/products/cdr/search (accessed 2014 Nov. 25)

15. Rotermann M, Langlois K, Andonov A, et al. Seroprevalence of hepatitis B and C virus infections: results from the 2007 to 2009 and 2009 to 2011 Canadian Health Measures Survey. Health Rep 2013;24:3-13.

16. Hepatitis: Ontario's use of funding provided by the federal hepatitis C undertaking agreement. Toronto: Ontario Ministry of Health and Long-Term Care; 2007.

17. TreeAge 2013 professional [software]. Williamstown (MA): TreeAge Software; 2013.

18. Berg T, von Wagner M, Nasser S, et al. Extended treatment duration for hepatitis $\mathrm{C}$ virus type 1 : comparing 48 versus 72 
weeks of peginterferon-alfa-2a plus ribavirin. Gastroenterology 2006;130:1086-97.

19. Berg T, Weich V, Teuber G, et al. Individualized treatment strategy according to early viral kinetics in hepatitis $\mathrm{C}$ virus type 1-infected patients. Hepatology 2009;50:369-77.

20. Bronowicki JP, Ouzan D, Asselah T, et al. Effect of ribavirin in genotype 1 patients with hepatitis $\mathrm{C}$ responding to pegylated interferon alfa-2a plus ribavirin. Gastroenterology 2006;131:1040-8.

21. Fried MW, Shiffman ML, Reddy KR, et al. Peginterferon alfa2a plus ribavirin for chronic hepatitis $\mathrm{C}$ virus infection. $N$ Engl $J$ Med 2002;347:975-82

22. Hadziyannis SJ, Sette H Jr, Morgan TR, et al. Peginterferonalpha2a and ribavirin combination therapy in chronic hepatitis C: a randomized study of treatment duration and ribavirin dose. Ann Intern Med 2004;140:346-55.

23. Hézode C, Forestier N, Dusheiko G, et al. Telaprevir and peginterferon with or without ribavirin for chronic HCV infection. N Engl J Med 2009;360:1839-50.

24. Jacobson IM, McHutchison JG, Dusheiko G, et al. Telaprevir for previously untreated chronic hepatitis $\mathrm{C}$ virus infection. N Engl J Med 2011;364:2405-16.

25. Kwo PY, Lawitz EJ, McCone J, et al. Efficacy of boceprevir, an NS3 protease inhibitor, in combination with peginterferon alfa$2 \mathrm{~b}$ and ribavirin in treatment-naive patients with genotype 1 hepatitis C infection (SPRINT-1): an open-label, randomised, multicentre phase 2 trial. Lancet 2010;376:705-16. Erratum in: Lancet 2010;376:1224.

26. Mangia A, Minerva N, Bacca D, et al. Individualized treatment duration for hepatitis $\mathrm{C}$ genotype 1 patients: a randomized controlled trial. Hepatology 2008;47:43-50.

27. Manns MP, McHutchison JG, Gordon SC, et al. Peginterferon alfa- $2 b$ plus ribavirin compared with interferon alfa- $2 \mathrm{~b}$ plus ribavirin for initial treatment of chronic hepatitis $\mathrm{C}$ : a randomised trial. Lancet 2001;358:958-65.

28. McHutchison JG, Everson GT, Gordon SC, et al. Telaprevir with peginterferon and ribavirin for chronic HCV genotype 1 infection. N Engl J Med 2009;360:1827-38.

29. McHutchison JG, Lawitz EJ, Shiffman ML, et al. Peginterferon alfa-2b or alfa-2a with ribavirin for treatment of hepatitis $\mathrm{C}$ infection. N Engl J Med 2009;361:580-93.

30. Poordad F, McCone J Jr, Bacon BR, et al. Boceprevir for untreated chronic HCV genotype 1 infection. N Engl J Med 2011;364:1195-206.

31. Roberts SK, Weltman MD, Crawford DH, et al. Impact of highdose peginterferon alfa- $2 \mathrm{~A}$ on virological response rates in patients with hepatitis $\mathrm{C}$ genotype 1: a randomized controlled trial. Hepatology 2009;50:1045-55.

32. Zeuzem S, Diago M, Gane E, et al. Peginterferon alfa-2a (40 kilodaltons) and ribavirin in patients with chronic hepatitis C and normal aminotransferase levels. Gastroenterology 2004; 127:1724-32.

33. Zeuzem S, Hultcrantz R, Bourliere M, et al. Peginterferon alfa$2 b$ plus ribavirin for treatment of chronic hepatitis $\mathrm{C}$ in previously untreated patients infected with HCV genotypes 2 or 3 . J Hepatol 2004;40:993-9.

34. Mangia A, Santoro R, Minerva N, et al. Peginterferon alfa- $2 b$ and ribavirin for 12 vs. 24 weeks in HCV genotype 2 or 3 . N Engl J Med 2005;352:2609-17.

35. Rizzetto M. Treatment of hepatitis $C$ virus genotype 2 and 3 with pegylated interferon plus ribavirin [letter]. J Hepatol 2005;42:275-6, author reply 276-7.

36. von Wagner M, Huber M, Berg T, et al. Peginterferon-alpha-2a (40KD) and ribavirin for 16 or 24 weeks in patients with genotype 2 or 3 chronic hepatitis C. Gastroenterology 2005;129:522-7.

37. Shiffman ML, Suter F, Bacon BR, et al. Peginterferon alfa-2a and ribavirin for 16 or 24 weeks in HCV genotype 2 or 3 N Engl J Med 2007;357:124-34.

38. Yu ML, Dai CY, Huang JF, et al. A randomised study of peginterferon and ribavirin for 16 versus 24 weeks in patients with genotype 2 chronic hepatitis C. Gut 2007;56:553-9.

39. Hasan F, Asker H, Al-Khaldi J, et al. Peginterferon alfa-2b plus ribavirin for the treatment of chronic hepatitis $\mathrm{C}$ genotype 4 . Am J Gastroenterol 2004;99:1733-7.

40. Alfaleh FZ, Hadad Q, Khuroo MS, et al. Peginterferon alpha-2b plus ribavirin compared with interferon alpha-2b plus ribavirin for initial treatment of chronic hepatitis $\mathrm{C}$ in Saudi patients commonly infected with genotype 4. Liver Int 2004;24:568-74

41. Kamal SM, El Tawil AA, Nakano T, et al. Peginterferon $\{$ alpha $\}-2 b$ and ribavirin therapy in chronic hepatitis $C$ genotype 4: impact of treatment duration and viral kinetics on sustained virological response. Gut 2005;54:858-66.

42. Sullivan P. New price tag put on liver transplants. CMAJ 2003; 168:206.

43. Gao X, Stephens JM, Carter JA, et al. Impact of adverse events on costs and quality of life in protease inhibitor-based combination therapy for hepatitis C. Expert Rev Pharmacoecon Outcome Res 2012:12:335-43.

44. Schedule of laboratory fees. Toronto: Ontario Ministry of Health and Long-Term Care; updated 2012. Available: www.health.gov .on.ca/english/providers/program/ohip/sob/lab/labfimmu.html (accessed 2014 May 1).

45. Chen W. Chronic hepatitis C among immigrants living in Canada: natural history, disease burden, and cost-effectiveness of screening [dissertation]. Toronto: University of Toronto; 2010.

46. Maddigan SL, Feeny DH, Johnson JA. Health-related quality of life deficits associated with diabetes and comorbidities in a Canadian National Population Health Survey. Qual Life Res 2005; 14:1311-20

47. Hsu PC, Federico CA, Krajden M, et al. Health utilities and psychometric quality of life in patients with early- and late-stage hepatitis C virus infection. J Gastroenterol Hepatol 2012;27:149-57.

48. McLernon DJ, Dillon J, Donnan PT. Health-state utilities in liver disease: a systematic review. Med Decis Making 2008;28:582-92

49. Yeung LT, To T, King SM, et al. Spontaneous clearance of childhood hepatitis $\mathrm{C}$ virus infection. J Viral Hepat 2007; 14:797-805

50. Rein DB, Smith BD, Wittenborn JS, et al. The cost-effectiveness of birth-cohort screening for hepatitis $\mathrm{C}$ antibody in US primary care settings. Ann Intern Med 2012;156:263-70.

51. Chaudhary R, Tepper M, Eisaadany S, et al. Distribution of hepatitis $\mathrm{C}$ virus genotypes in Canada: results from the LCDC Sentinel Health Unit Surveillance System. Can J Infect Dis 1999;10:53-6.

52. Charlton M, Seaberg E, Wiesner R, et al. Predictors of patient and graft survival following liver transplantation for hepatitis $\mathrm{C}$. Hepatology 1998;28:823-30.

53. Thein HH, Yi Q, Dore GJ, et al. Estimation of stage-specific fibrosis progression rates in chronic hepatitis $\mathrm{C}$ virus infection: meta-analysis and meta-regression. Hepatology 2008;48:418-31.

54. van der Meer AJ, Veldt BJ, Feld JJ, et al. Association between sustained virological response and all-cause mortality among patients with chronic hepatitis $\mathrm{C}$ and advanced hepatic fibrosis. JAMA 2012;308:2584-93.

55. Altekruse SF, McGlynn KA, Reichman ME. Hepatocellular carcinoma incidence, mortality, and survival trends in the United States from 1975 to 2005. J Clin Oncol 2009;27:1485-91.

56. D'Amico G, Garcia-Tsao G, Pagliaro L. Natural history and prognostic indicators of survival in cirrhosis: a systematic review of 118 studies. J Hepatol 2006;44:217-31.

57. Krahn M, Wong JB, Heathcote J, et al. Estimating the prognosis of hepatitis $\mathrm{C}$ patients infected by transfusion in Canada between 1986 and 1990. Med Decis Making 2004;24:20-9.

58. Guidelines for the economic evaluation of health technologies: Canada. 3rd ed. Toronto: Canadian Agency for Drugs and Technologies in Health; 2006. Available: www.cadth.ca/media /pdf/186_EconomicGuidelines_e.pdf (accessed 2014 Nov. 25).

59. Krajden M, Kuo M, Zagorski B, et al. Health care cost associated with hepatitis C: a longitudinal cohort study. Can J Gastroenterol 2010;24:717-26.

60. Salomon JA, Weinstein MC, Hammitt JK, et al Costeffectiveness of treatment for chronic hepatitis $\mathrm{C}$ infection in an evolving patient population. JAMA 2003;290:228-37.

61. Wong JB, Bennett WG, Koff RS, et al. Pretreatment evaluation of chronic hepatitis $\mathrm{C}$ : risks, benefits, and costs. JAMA 1998;280:2088-93.

62. Eckman MH, Talal AH, Gordon SC, et al. Cost-effectiveness of screening for chronic hepatitis $\mathrm{C}$ infection in the United States. Clin Infect Dis 2013;56:1382-93

63. Liu S, Cipriano LE, Holodniy M, et al. Cost-effectiveness analysis of risk-factor guided and birth-cohort screening for chronic hepatitis $\mathrm{C}$ infection in the United States. PLOS ONE 2013;8:e58975.

64. Sherman M. Hepatitis C: the juggernaut rolls on unchecked Can J Gastroenterol 2008;22:355-6.

65. Myers RP, Liu M, Shaheen AA. The burden of hepatitis C virus infection is growing: a Canadian population-based study of hospitalizations from 1994 to 2004. Can J Gastroenterol 2008;22:381-7

66. Kowdley KV, Gordon SC, Reddy KR, et al. Ledipasvir and sofosbuvir for 8 or 12 weeks for chronic $\mathrm{HCV}$ without cirrhosis. N Engl J Med 2014;370:1879-88.

67. Afdhal N, Zeuzem S, Kwo P, et al. Ledipasvir and sofosbuvir for untreated HCV genotype 1 infection. N Engl J Med 2014; 370:1889-98

68. Afdhal N, Reddy KR, Nelson DR, et al. Ledipasvir and sofosbuvir for previously treated HCV genotype 1 infection. N Engl J Med 2014;370:1483-93. 
69. Zeuzem S, Jacobson IM, Baykal T, et al. Retreatment of HCV with ABT-450/r-ombitasvir and dasabuvir with ribavirin. N Engl J Med 2014;370:1604-14.

70. Saab S, Brezina M, Gitnick G, et al. Hepatitis C screening strategies in hemodialysis patients. Am J Kidney Dis 2001;38:91-7.

71. Averhoff FM, Glass N, Holtzman D. Global burden of hepatitis C: considerations for healthcare providers in the United States. Clin Infect Dis 2012;55 Suppl 1:S10-5.

72. Tomkins SE, Elford J, Nichols T, et al. Occupational transmission of hepatitis $\mathrm{C}$ in healthcare workers and factors associated with seroconversion: UK surveillance data. J Viral Hepat 2012;19:199-204.

73. Carney K, Dhalla S, Aytaman A, et al. Association of tattooing and hepatitis $\mathrm{C}$ virus infection: a multicenter case-control study. Hepatology 2013;57:2117-23.

74. Strehlow AJ, Robertson MJ, Zerger S, et al. Hepatitis C among clients of health care for the homeless primary care clinics. $J$ Health Care Poor Underserved 2012;23:811-33.

Affiliations: Toronto Health Economics and Technology Assessment Collaborative, Leslie Dan Faculty of Pharmacy (W. Wong, Krahn), and Institute of Health Policy, Manage- ment and Evaluation (Tu), University of Toronto, Toronto, Ont.; Toronto Centre for Liver Disease, University Health Network (Feld), Toronto, Ont.; Public Health Agency of Canada (T. Wong), Ottawa, Ont.

Contributors: William Wong implemented the model, collected and analyzed the data, and drafted the manuscript. Hong-Anh Tu contributed to acquisition of data. Jordan Feld contributed to acquisition and interpretation of data. Tom Wong and Murray Krahn contributed to design of the study and analysis and interpretation of the data. All authors contributed to revising the manuscript for important intellectual content, gave final approval of the version to be published and agree to act as guarantors for the article.

Funding: This study was supported by the Public Health Agency of Canada.

Acknowledgments: The authors would like to express appreciation to Dr. David Wong, Dena Schanzer and Dana Paquette for their valuable suggestions and insights during the conduct of this study. 